2004

\title{
Innocent Spouses: A Critique of the New Tax Laws Governing Joint and Several Tax Liability
}

Lily Kahng

Follow this and additional works at: https://digitalcommons.law.villanova.edu/vlr

Part of the Tax Law Commons

\section{Recommended Citation}

Lily Kahng, Innocent Spouses: A Critique of the New Tax Laws Governing Joint and Several Tax Liability, 49 Vill. L. Rev. 261 (2004).

Available at: https://digitalcommons.law.villanova.edu/vlr/vol49/iss2/1

This Article is brought to you for free and open access by Villanova University Charles Widger School of Law Digital Repository. It has been accepted for inclusion in Villanova Law Review by an authorized editor of Villanova University Charles Widger School of Law Digital Repository. 


\title{
VILLANOVA LAW REVIEW
}

VOLUME 49

Number 2

\section{Article}

\section{INNOCENT SPOUSES: A CRITIQUE OF THE NEW TAX LAWS GOVERNING JOINT AND SEVERAL TAX LIABILITY}

\author{
LILY KAHNG*
}

\section{INTRODUCTION}

$\mathrm{T}$ HE new innocent spouse laws are rapidly and dramatically reshaping the contours of joint and several liability for married taxpayers filing joint returns. ${ }^{1}$ As this process occurs, the new laws should be interpreted

* Associate Professor, Seattle University School of Law. A.B., 1980, Princeton University; J.D., 1984, Columbia Law School; LL.M. (Taxation), 1991, New York University Law School. The author wishes to thank Sheldon Frankel, Katherine Pratt, Christopher Rizek, John Siliciano and Gregory Silverman for their helpful comments.

This Article draws on the author's experiences and research while in the Office of Tax Legislative Counsel, Department of Treasury. The opinions expressed in the Article are solely those of the author and do not reflect the views of the Department of Treasury.

1. The level of activity surrounding the innocent spouse laws within the legal system has been astonishing. During the first year alone after passage of the new law, then IRS Commissioner Charles Rossotti estimated that 27,000 claims for relief under the new law were made. See Amy Hamilton, Lawmakers Track IRS Reform One Year Later, 84 TAx Notes 517, 519 (July 26, 1999) (discussing problems with processing innocent spouse claims). In each of fiscal years 1999, 2000 and 2001, the IRS received approximately 50,000 cases. See Tax Administration: IRS's InNocent Spouse Program Performance Improved; Balanced Performance Measures Needed, General Accounting Office Report to the Chairman and Ranking MiNORITY Member, S. COMm. ON Fin. tbl. 4 (Apr. 2002), available at http:// www.unclefed.com/GAOReports/99002-558.pdf (showing innocent spouse cases received and decided by IRS in 1999-2001). During those same years, courts decided dozens of innocent spouse cases. See id. tbls. 7, 8 (noting innocent spouse cases litigated in Tax Court and circuit courts).

Two unusual features of the 1998 Act's innocent spouse rules account for the flurry of administrative and judicial activity with respect to the new law. First, the new law is retroactive: any spouse with an unpaid deficiency as of July 22, 1998, became eligible to seek relief under the new law. See Internal Revenue Restructuring and Reform Act of 1998, Pub. L. No. 105-206, § 3201, 112 Stat. 685, 740 (1998) (setting effective dates for new innocent spouse provisions). The new law also applies to liabilities arising after July 22, 1998. See id. Second, the new law requires the IRS to make determinations quickly and, if a determination is adverse, provides the taxpayer immediate review by Tax Court review. See id. Taxpayers have 
and implemented in a manner consistent with a cohesive underlying theory of the tax treatment of married individuals. This Article provides a framework for such interpretation and implementation. Part II of this Article presents an overview of the current tax law treatment of married joint filers, under which joint and several liability is imposed unless relief is available under the new innocent spouse laws. Part III examines the tax rationales that have traditionally been offered for imposing joint and several liability. Part III concludes that the principal rationale for joint and several liability-marital unity-is little more than a fiction adopted by lawmakers and scholars in order to rationalize a political compromise between community property and common law states. Furthermore, the other, secondary justifications for joint and several liability are unsatisfactory at best. Part IV then explores joint and several liability in other areas of law such as tort, agency and fraudulent transfer and identifies fairness and efficiency as the principal policy grounds for imposing joint and several liability. Finally, Part V uses these policy criteria of fairness and efficiency to evaluate the current tax law treatment of married joint filers. Part V recommends that the new innocent spouse laws be interpreted or reformed to effectuate these policies.

\section{Current Law: Joint and Several Liability; INNOCENT SPOUSE RELIEF}

\section{A. Joint and Several Liability}

At the first level, our federal income tax system is one of self-assessment. A taxpayer is required to report items of income, deduction, gain and loss on a return and compute her taxable income and the tax thereon. The taxpayer must sign and file the return, and pay the amount of tax shown due. ${ }^{2}$ The Internal Revenue Service (IRS) is authorized to review and challenge the self-assessed tax liability, and through administrative and judicial proceedings, the taxpayer may ultimately be found to be liable for a deficiency - the difference between the correct tax due and the amount of tax shown on the return. ${ }^{3}$ The deficiency may also include interest charges ${ }^{4}$ on taxes paid later than their due date and penalties for failure to self-assess and pay the correct amount of tax due. ${ }^{5}$

ninety days to petition the Tax Court for review if the IRS either makes an adverse determination on a claim for relief or fails to make a final determination within six months after a claim for relief is made. See I.R.C. \$6015(e)(1) (2003).

2. See I.R.C. $\$ \$ 6011$ (a), 6151(a) (2003) (discussing general requirements for filing income tax returns).

3. See generally Michael I. Saltzman, IRS Practice and Procedure ch. 10 (2d ed. 1991) (discussing procedures for assessing income tax).

4. See I.R.C. $\$ 6601$ (2002).

5. See I.R.C. $\$ \S 6601,6651-6751$ (2003). 
A husband and wife who choose to file a joint federal income tax return engage in this self-assessment process jointly. ${ }^{6}$ The joint return aggregates items of income, deduction, gain and loss attributable to either spouse; taxable income is computed in the aggregate, and the tax due is a single amount. ${ }^{7}$ If a joint return is made, each spouse undertakes to pay the entire amount of tax shown due. ${ }^{8}$ Furthermore, each spouse assumes joint and several liability for the entire amount of any subsequently determined deficiency. ${ }^{9}$

From a collection standpoint, joint and several liability allows the IRS to collect from either spouse the full amount of any deficiency. If the IRS collects the entire amount of a deficiency from one spouse, that spouse

6. See I.R.C. \$6013(a) (2003) (authorizing joint returns for married taxpayers). Married couples may choose either to file a joint return or to file separate returns. See id. As a practical matter, most married couples file jointly. See InTERnal Revenue Service, U.S. Dep't of Treasury, Publication 1304, Statistics of InCOMe-1993 Individual Income Tax Returns 80 (1996) (charting returns by marital status). In 1993, an estimated $96.3 \%$ of all married couples filed jointly. See id. Most married taxpayers file jointly because it is simpler, it rarely results in a higher tax liability and it often results in a lower tax liability than filing separately. See Amy C. Christian, The Joint Return Rate Structure: Identifying and Addressing the Gendered Nature of the Tax Law, 13 J.L. \& PoL. 241, 261-73 (1997) (discussing differences between joint and separate filing). The tax benefits of filing jointly derive primarily from the rate structures governing joint and separate filers. See id.

The option to file a joint return for married couples was introduced in 1918, shortly after the introduction of the income tax in 1913. See Richard C.E. Beck, The Innocent Spouse Problem: Joint and Several Liability for Income Taxes Should Be Repealed, 43 VAND. L. Rev. 317, 333 (1990) (discussing origins of joint return liability). For a detailed history of the joint return and joint and several liability, see $i d$. at 332-47 (surveying history of joint return liability) and Amy C. Christian, Joint and Several Liability and the Joint Return: Its Implications for Women, 66 U. CiN. L. REv. 535, 538-72 (1998) (surveying history of joint return liability) [hereinafter Christian I].

7. See I.R.C. $\$ 6013$ (d) (3) (2003); Treas. Reg. $\$ 1.6013-4$ (b) (2003).

8. See I.R.C. \& 6013(d) (3).

9. See id. A joint return is required to be signed by both spouses. See Treas. Reg. $\$ 1.6013-(1)$ (a) (2) (2003). If a spouse fails to sign the return, it may be found to be an invalid joint return, and joint and several liability will not attach. See Carrick v. Comm'r, 62 T.C.M. (CCH) 938, 942 (1991) (declining to assess liability against non-signing spouse); $c f$. Brown v. Comm'r, 51 T.C. 116, 120-21 (1968) (declining to assess liability for spouse who signed return under duress). However, failure to sign a return is not dispositive; rather, the intention of the parties is determinative. See Noonan v. Comm'r, 73 T.C.M. (CCH) 1740, 1743 (1997) (holding ex-wife liable despite her refusal to sign joint return she consented because of previous contractual agreement); Hoyle v. Comm'r, 68 T.C.M. (CCH) 1321, 133233 (1994) (finding insufficient evidence of intended joint return when husband signed spouse's name).

A joint return is also invalid if a spouse signed under duress. See, e.g., Brown, 51 T.C. at 119 (finding no joint return when spouse's signature executed under duress). Establishing duress has proved burdensome, and taxpayers often fail. See, e.g., Stanley v. Comm'r, 45 T.C. 555, 562-63 (1966) (holding that despite fear of husband, spouse's signature was not made under duress); Federbush v. Comm'r, 34 T.C. 740,757 (1960), affd per curiam, 325 F.2d 1 (2d Cir. 1963) (holding that despite testimony that husband was abusive, spouse's signature was not made under duress); Estate of Aylesworth v. Comm'r, 24 T.C. 134, 146 (1955) (holding that despite marital difficulties, spouse's signature was not made under duress). 
has contribution rights against the other spouse for the portion of the deficiency attributable to the other spouse. ${ }^{10}$ In situations like this, little is known about the extent to which contribution rights are actually pursued or lead to recovery. Nevertheless, the IRS often pursues one spouse rather than the other because prospects of recovering from the other spouse are poor (e.g., the other spouse is judgment-proof, has no attachable income stream or the other spouse's whereabouts are unknown). ${ }^{11}$ From this, one can surmise that the enforcement of contribution rights against this other spouse occurs relatively rarely. ${ }^{12}$

\section{B. Innocent Spouse Relief}

\section{Pre-1998 Law}

Under certain circumstances, a spouse may be relieved from liability arising from a joint return she has signed. The first statute providing for this so-called innocent spouse relief was enacted in $1971 .^{13}$ Prior to its repeal in $1998,{ }^{14}$ it authorized the IRS to relieve a spouse from joint and several liability for a deficiency if three conditions were met: (1) there was

10. See, e.g., Murchison v. Murchison, 33 Cal. Rptr. 285, 288 (Dist. Ct. App. 1963) (upholding contribution rights regarding obligations from joint return); Chappell v. Chappell, 253 So. 2d 281, 282-83 (Fla. Dist. Ct. App. 1971) (recognizing contribution rights of spouse regarding obligations from joint returns); see also Beck, supra note 6, at 331 (discussing contribution); Richard C.E. Beck, The Innocent Spouse Rules, 15 FAM. ADvoc. 30, 32 (Fall 1992) (discussing protections against tax liability arising from joint returns).

11. See Kari Smoker, Comment, Internal Revenue Service Restructuring and Reform Act of 1998: Expanded Relief for Innocent Spouses-At What Cost? A Feminist Perspective, 60 Oнно ST. L.J. 2045, 2063 (1999) (discussing problems arising from joint and several liability from joint tax returns).

12. See Richard C.E. Beck, The Deductibility of a Worthless Right to Contribution for Joint Income Taxes: The Mistaken Line of Cases Under Rude v. Commissioner, 9 VA. TAX Rev. 313, 314-15 (1989) (noting worthlessness of contribution rights).

13. See Act of Jan. 12, 1971, Pub. L. No. 91-679, § 1, 84 Stat. 2063, 2063 (1971). The 1971 statute was enacted to address cases like Scudder v. Commissioner, 48 T.C. 36, 41 (1967), rev'd and remanded, 405 F.2d 222 (6th Cir. 1969). In that case, Frank Scudder embezzled hundreds of thousands of dollars from a wholesale liquor business owned by his wife, Louise Scudder, and her sisters. See id. at 37. Frank failed to report the embezzled income on their joint return. See id. at 37-38. The Tax Court reluctantly held Louise jointly and severally liable for the deficiency, decrying the harsh result and suggesting the need for legislation. See id. at 41. When Congress finally enacted the innocent spouse statute, the legislative history cited Scudder as a reason for the change in law. See H.R. ReP. No. 91-1734, at 2 (1970) (noting several innocent spouse cases and quoting from Scudder). The statute was significantly modified in 1984 and, until its repeal in 1998, remained in effect in substantially the same form. See Deficit Reduction Act of 1984, Pub. L. No. 98-369, § 424(a), 98 Stat. 494, 801-03 (1984) (amending innocent spouse laws).

14. See I.R.C. $\S 6013(\mathrm{e})$ (1998) [hereinafter Old $\S 6013(\mathrm{e})]$, repealed by Internal Revenue Restructuring and Reform Act of 1998, Pub. L. No. 105-206, 112 Stat. 685 (1998). 
a "substantial understatement" 15 of tax attributable to "grossly erroneous" 16 items of the other spouse; ${ }^{17}$ (2) the spouse requesting relief established that, in signing the return, she did not know, and had no reason to know, of the substantial understatement; ${ }^{18}$ and (3) taking into account all the facts and circumstances, it would be inequitable to hold the requesting spouse liable for the deficiency attributable to the understatement. ${ }^{19}$

Most of the cases interpreting the "knowledge" requirement of the statute focused on the "reason to know" rather than the "knowledge" component. ${ }^{20}$ In determining whether the reason-to-know requirement had been met, courts generally conducted a multi-factor inquiry that included: (1) the level of education of the spouse seeking relief; (2) her involvement in family finances and business affairs; (3) the presence of lavish or extravagant expenditures; and (4) the extent to which the other spouse was deceitful or evasive with regard to family finances. ${ }^{21}$ If a spouse knew, or had

15. See Old $\$ 6013$ (e)(1)(B). An understatement is generally defined to be the difference between the correct amount due and the amount of tax shown on the return. See Old $\S 6013$ (e); see also I.R.C. $\$ 6662$ (d) (2)(A) (2003).

There were two components to the definition of substantial understatement. The first required the understatement to exceed $\$ 500$. See Old $\$ 6013$ (e) (3). The second required that, if the understatement related to a deduction, credit or basis, it exceed a percentage of the requesting spouse's adjusted gross income for the year before the notice of deficiency was mailed, $10 \%$ for an adjusted gross income of up to $\$ 20,000$ and $25 \%$ for an adjusted gross income greater than $\$ 20,000$. See Old $\$ 6013(\mathrm{e})(4)$.

16. See Old $\S 6013(\mathrm{e})(1)(\mathrm{C})$. A grossly erroneous item was an omission from gross income or a deduction, credit or basis for an amount in which there was no basis in law or in fact. See Old $\$ 6013(\mathrm{e})(2)$. The "no basis in law or fact" was undefined in the statute and led to inconsistent and confusing results in the courts. See Jerome Borison, Innocent Spouse Relief: A Call for Legislative and Judicial Liberalization, 40 TAX LAw. 819, 842-60 (1987) (discussing cases interpreting "no basis in law or fact" clause).

17. See Old $\$ 6013$ (e)(1)(D). When an erroneous item is related to services performed or property owned by one spouse, it is generally treated as that spouse's item. See Keene v. Comm'r, 38 T.C.M. (CCH) 553, 555-56 (1979) (finding husband liable for omitted income earned by and allocated to him, even though wife prepared return). The courts have interpreted this requirement to mean that, in order to qualify for relief, the erroneous item must be solely allocable to the other spouse. See id. at 555. Thus, when an item is related to activities of both spouses or property owned by both spouses, the item is allocated to both spouses and the spouse seeking relief is denied relief. See Hayman v. Comm'r, 992 F.2d 1256, 126061 (2d Cir. 1993) (denying relief to wife after allocating erroneous deductions made jointly by husband and wife to both spouses).

18. See Old $\S 6013(\mathrm{e})(1)(\mathrm{C})$.

19. See Old $\S 6013$ (e)(1) (D).

20. This is probably true for two reasons. First, determining whether a spouse had "reason to know" is the sort of facts-and-circumstances finding that parties can reasonably debate. In contrast, whether a spouse has knowledge of an erroneous item is difficult to prove or disprove. Second, all that is necessary to disqualify a spouse from relief was a finding that she met the less stringent "reason to know" standard.

21. See Reser v. Comm'r, 112 F.3d 1258, 1267 (5th Cir. 1997) (stating standard of inquiry in joint return liability cases); Resser v. Comm'r, 74 F.3d 1528, 1535-36 (7th Cir. 1996) (stating standard for evaluating whether taxpayer had reason to 
reason to know, some but not all of an understatement, courts allowed partial relief to be granted. ${ }^{22}$ Courts consistently interpreted the knowledge requirement to mean that the spouse knew, or had reason to know, of the existence of an erroneous item, not of its correct tax treatment. ${ }^{23}$

In determining whether the "equity" requirement of the statute was satisfied, courts tended to place great weight on whether the spouse seeking relief significantly benefited from the understatement. ${ }^{24}$ This is con-

know); Kistner v. Comm'r, 18 F.3d 1521, 1525 (11th Cir. 1994) (discussing test for "reason to know" in joint return liability cases); Pietromonaco v. Comm'r, 3 F.3d 1342, 1345 (9th Cir. 1993) (discussing objective standard for "reason to know" in joint return liability cases); Hayman, 992 F.2d at 1261 (discussing relevant inquiry in joint return liability cases); Stevens v. Comm'r, 872 F.2d 1499, 1505 (11th Cir. 1989) (discussing "reason to know" standard in innocent spouse test). In some cases, courts have articulated the "reason to know" standard as whether a reasonably prudent taxpayer in his or her position could be expected to know that the stated tax liability was erroneous or that further investigation was warranted. Pietromonaco, 3 F.3d at 1345 (using "reasonably prudent taxpayer" standard); Stevens, 872 F.2d at 1505 (applying standard of whether "a reasonably prudent taxpayer under the circumstances of the spouse at the time of signing the return could be expected to know that the tax liability was erroneous or that further investigation was warranted"); Silverman v. Comm'r, 67 T.C.M. (CCH) 2631, 2634 (1994) (noting that taxpayer is liable if "a reasonably prudent person in his or her position could be expected to know that the stated tax liability was erroneous or that further investigation was warranted"). See generally Stephen A. Zorn, Innocent Spouses, Reasonable Women and Divorce: The Gap Between Reality and the Internal Revenue Code, 3 Mich. J. GENDER \& L. 421, 449-57 (1996) (discussing factors considered by courts in determining "reason to know" in joint return liability disputes).

22. See Wiksell v. Comm'r, 90 F.3d 1459, 1463 (9th Cir. 1996) (allowing partial relief to spouse who had no reason to know of magnitude of understatement); Ballard v. Comm'r, 740 F.2d 659, 664 (8th Cir. 1984) (allowing relief to spouse for joint return omissions despite her knowledge of related items); Ratana v. Comm'r, 662 F.2d 220, 224-25 (4th Cir. 1981) (allowing partial relief from liability to spouse with knowledge of some omissions but no reason to know of others); see also Laura Lee Mannino, Note, Breaking the Taxing Bonds of Marriage: Partial Relief for the Innocent Spouse, 26 Hofstra L. Rev. 477, 494501 (1997) (discussing partial relief in joint liability actions).

23. See Reser, 112 F.3d at 1265 (inquiring whether spouse "knew or should have known of income-producing transaction"); Bokum v. Comm'r, 992 F.2d 1132, 1131 (11th Cir. 1993) ("[W]e refuse to find that spouses who are mistaken about the operation of the tax law are nevertheless released from liability."); Stevens, 872 F.2d at 1504-05 (analyzing whether spouse "knew or had reason to know" of "phony deductions," not whether spouse knew the law); Sanders v. United States, 509 F.2d 162, 169 (5th Cir. 1975) (examining whether spouse knew or had reason to know of erroneous transaction); McCoy v. Comm'r, 57 T.C. 732, 734 (1972) (finding no relief from liability when lack of knowledge was "predicated on mere ignorance of the legal tax consequences of transactions"); see also Paul F. Wright, Comment, Taxation-Innocent Spouse Provision-Of Erroneous Deductions and Decisions -From 6013(e) to 6015-The Knowledge Requirement and the Erroneous Deduction Quagmire of the Internal Revenue Code, 39 S. Tex. L. Rev. 845, 859-62 (1998) (discussing "knowledge of the transaction" test); Courts Split over "Knowledge" of Innocent Spouses, $72 \mathrm{~J}$. TAx'N 314, 314-15 (Jacquin D. Bierman \& Steven L. Severin eds., 1990) (discussing court decisions requiring either knowledge of transaction or knowledge of tax consequences of transaction).

24. See Buchine v. Comm'r, 20 F.3d 173, 181 (5th Cir. 1994) (describing most important factor in equity test as whether taxpayer benefited significantly from tax 
sistent with the 1984 legislation, which deleted the reference to significant benefit from the statute, but directed in legislative history that significant benefit continue to be taken into account. ${ }^{25}$ Other factors taken into account included whether the other spouse deserted the spouse seeking relief and whether the spouses are divorced or separated. ${ }^{26}$

\section{1998 Act}

\section{a. Prior Law Liberalized}

The Internal Revenue Service Restructuring and Reform Act of $1998^{27}$ (the "1998 Act") changed the innocent spouse provisions in several significant respects. ${ }^{28}$ The 1998 Act liberalized the prior-law relief provision ("traditional relief") by eliminating the requirements that there be a "substantial" understatement of tax attributable to a "grossly" erroneous item of the other spouse. Now all that is required is an understatement of tax attributable to an erroneous item of the other spouse. ${ }^{29}$ The other prior-law requirements for traditional relief-in particular, the knowledge and equity requirements-remain unchanged.

\section{b. New "Proportionate Relief"}

The 1998 Act also added two new forms of relief from joint and several liability. The first allows a spouse to elect to limit her liability for a deficiency to her allocable share of the deficiency. ${ }^{30}$ The deficiency is allocated in the same proportion that the spouse's erroneous items bear to the total amount of erroneous items giving rise to the deficiency. ${ }^{31}$ For example, assume a $\$ 10,000$ deficiency is assessed with respect to a joint return. The deficiency arises from $\$ 30,000$ of underreported income of one spouse and $\$ 20,000$ of overstated deductions of the second spouse. If

understatement); Purificato v. Comm'r, 9 F.3d 290, 296 (3d Cir. 1993) (noting that court will be more likely to grant relief if spouse did not specifically benefit from understatement); Ebeling v. Comm'r, 67 T.C.M. (CCH) 3102, 3104 (1994) (finding no inequity in not granting relief to taxpayer with "lavish lifestyle").

25. See H.R. ReP. No. 98-432, pt. 2, at 1502 (1984) (explaining reasons for change in law).

26. See, e.g., Estate of Krock v. Comm'r, 93 T.C. 672, 677-79 (1989) (discussing other factors to consider in determining inequity).

27. Pub. L. No. 105-206, $\$ 3201,112$ Stat. 685,734 (codified at I.R.C. $\$ 6015$ ).

28. For an informative account of the enactment of the 1998 Act innocent spouse provisions, see Toni Robinson \& Mary Ferrari, The New Innocent Spouse Provision: "Reason and Law Walking Hand in Hand"?, 80 TAX Notes 835, $841-48$ (1998).

29. See I.R.C. $\$ 6015$ (b) (1)(B) (2003).

30. See I.R.C. $\$ 6015$ (c) (1) (2003).

31. See I.R.C. $\$ 6015$ (d) (1) (2003). Items are generally allocated in the same manner as if the individuals had filed separate returns for the year. See I.R.C. $\$ 6015$ (d)(3)(A) (2003). The Treasury Department has interpreted this to mean that income and deductions relating to the business activities of one spouse are allocated to that spouse, and income and deductions relating to property owned by one spouse are allocated to that spouse. See Treas. Reg. $\$ 1.6015-3$ (d) (2) (ii), (iii) (2003). 
the first spouse so elects, her liability for the deficiency will be limited to a fraction of the total liability, with her erroneous item as the numerator of the fraction and the total amount of erroneous items as the denominator. Thus, her liability will be limited to $\$ 6,000(\$ 10,000 \times \$ 30,000 / \$ 50,000) .^{32}$

This first new form of relief ("proportionate relief") is available only to a spouse who-at the time she elects such relief-is divorced or legally separated from the other spouse, or has lived apart from the other spouse during the twelve-month period ending on the date relief is elected. ${ }^{33}$ The general allocation method described in the preceding paragraph is subject to various modifications and exceptions to ensure an appropriate allocation of liability. ${ }^{34}$ In addition, proportionate relief is unavailable if assets are transferred from one to the other with the principal purpose of tax avoidance or if one or both spouses act fraudulently. ${ }^{35}$ Finally, a spouse is not relieved of liability for any portion of the deficiency attributa-

32. See H.R. Conf. ReP. No. 105-599, at 252-53 (1998) (providing detailed examples); see also Treas. Reg. $\$ 1.6015-3$ (d) (5), exs. 1-6. The election to limit liability applies only to the spouse making the election; the non-electing spouse remains liable for the entire deficiency.

33. See I.R.C. $\$ 6015$ (c) (2003). It is difficult to discern the policy rationale for so limiting this form of relief. Indeed, as has been gleefully pointed out by a former Treasury official involved with the legislation, the Republican-controlled Congress that passed the 1998 Act appears to have unwittingly enacted a relief provision that rewards those whose marriages are no longer intact. See Interview with Christopher Rizek, Associate Tax Legislative Counsel (Nov. 14, 1998). In reality, limiting the relief to this subset of joint return filers is the result of a compromise between those who wanted it available to all joint filers and those who did not want it at all. Robinson \& Ferrari, supra note 28, at 844-45 (explaining compromise between opponents).

34. To the extent that the erroneous item of one spouse gives rise to a tax benefit to the other spouse (e.g., one spouse's deductions reduce other spouse's income), that item is allocated to the other spouse. See I.R.C. $\$ 6015$ (d) (3) (B) (2003); see also H.R. Conf. REP. No. 105-599, at 252 (1998). A disallowed credit or the imposition of special taxes (taxes other than the income tax or the alternative minimum tax, such as the self-employment tax) related to one spouse's erroneous item is allocated directly to that spouse dollar-for-dollar and the remaining deficiency is allocated in accordance with the general allocation method described above. See I.R.C. $\S 6015$ (d) (2) (2003); see also H.R. Conf. Rep. No. 105-599, at 253 (1998).

35. A spouse's allocated share of a deficiency is increased by the value of any "disqualified assets" transferred to the spouse by the other spouse. See I.R.C. $\$ 6015$ (c)(4)(A) (2003). A disqualified asset is defined as an asset transferred from one spouse to the other if the principal purpose of the transfer was tax avoidance. See I.R.C. $\$ 6015$ (c)(4)(B)(i) (2003). An asset transferred from the other spouse to the spouse electing relief is presumed to be for the principal purpose of tax avoidance if it is transferred within one year after the first notice of proposed deficiency allowing for administrative review in the Internal Revenue Service Office of Appeals is sent, unless the spouse rebuts the presumption or unless the transfer is made pursuant to a divorce or separate maintenance decree. See I.R.C. $\$ 6015$ (c) (4)(B) (ii) (2003). The IRS may depart from the general allocation method if it establishes that such a departure is appropriate due to fraud of one or both spouses. See I.R.C. $\$ 6015$ (c) (3) (A) (ii) (2003). The spouses are ineligible to elect to allocate liability if the IRS demonstrates that assets were transferred between them as part of a fraudulent scheme. See I.R.C. $\$ 6015$ (d) (3) (C) (2003). 
ble to an item of the other spouse if the IRS demonstrates that the spouse seeking relief had actual knowledge of the item at the time she signed the return. ${ }^{36}$

In contrast to traditional relief, where mere "reason to know" of an erroneous item is sufficient to disqualify a spouse from relief, proportionate relief is precluded only if the spouse has "actual knowledge" of an erroneous item. ${ }^{37}$ The legislative history states that "actual knowledge must be established by the evidence and shall not be inferred based on indications that the electing spouse had a reason to know." 38 This suggests that the actual knowledge test is qualitatively different from the reason-to-know test in that actual knowledge cannot be inferred from evidence such as the spouse's education, financial acumen and involvement in the family business affairs. ${ }^{39}$ As under traditional relief, mere knowledge of an erroneous item, and not its tax treatment, has been held to be sufficient to meet the "actual knowledge" test. ${ }^{40}$

\section{c. New "Equitable Relief"}

The second new form of relief created by the 1998 Act ("equitable relief") is a residual provision, authorizing the IRS to provide relief in situations where neither traditional nor proportionate relief is available, but it would be inequitable to hold the spouse liable. ${ }^{41}$ The legislative history cites as an example the situation where there is no understatement of tax, but there is an underpayment of tax-that is, the return correctly reports

36. See I.R.C. $\$ 6015$ (c) (3) (C) (2003).

37 . In addition, the IRS must demonstrate that the spouse had actual knowledge, in contrast to traditional relief, where the spouse must prove that she did not know, or have reason to know, of the understatement. See H.R. Conf. Rep. No. 105-599, at 253 (1998).

38. $I d$.

39. See Cheshire v. Comm'r, 115 T.C. 183, 195 (2000), aff'd, 282 F.2d 326 (5th Cir. 2002) (actual knowledge is "an actual and clear awareness (as opposed to reason to know) of the existence of an item"); Wiksell v. Comm'r, 77 T.C.M. (CCH) 1336, 1337 (1999), aff'd, 215 F.3d 1335 (9th Cir. 2000) (explaining that actual knowledge is demonstrated by fact that wife questioned husband about items of income not shown on return).

Actual knowledge would clearly be demonstrated by, for example, an admission by the spouse that she had actual knowledge of an item. Such admissions are not uncommon in the administration of innocent spouse cases. The Treasury Department cites, as factors that go towards establishing actual knowledge, whether the spouse made a deliberate effort to avoid learning of an erroneous item and whether the spouses had joint ownership of the property giving rise to an erroneous item. See Treas. Reg. $\$ 1.6015-3$ (c) (2) (iv) (2003).

40. Cheshire v. Comm'r, 282 F.2d 326, 337 (5th Cir. 2002) (stating actual knowledge is knowledge of facts and circumstances that made item allowable as deduction); Mitchell v. Comm'r, 292 F.3d 800, 806 (D.C. Cir. 2002) (holding I.R.C. $\$ 6015$ (c) (3) (C) "does not require the IRS to show that an individual seeking subsection (c) relief had actual knowledge of the improper tax treatment").

41. See I.R.C. $§ 6015$ (f) (2003). 
the couple's tax liability, but the liability is not paid. ${ }^{42}$ In this situation, neither traditional nor proportionate relief is available because both of these require that there be an understatement of tax. ${ }^{43}$ The legislative history envisions the third relief provision possibly applying in the underpayment situation. The legislative history also makes clear that this is not the only instance where residual relief might be available. ${ }^{44}$

There has been relatively little interpretation of the equitable relief provision. The Treasury Department's published guidance specifically addresses the underpayment situation contemplated by the legislative history, setting forth a safe harbor under which relief will ordinarily be granted. ${ }^{45}$ The guidance also sets forth a non-exhaustive list of factors the Treasury Department considers relevant in determining whether to grant equitable relief. ${ }^{46}$ The courts have yet to fully address the scope and applicability of the equitable relief provision, generally deferring to the IRS's discretion in determining whether to grant relief. ${ }^{47}$ In several cases in the past year, however, the Tax Court has overturned the IRS's determination not to grant equitable relief and substituted its own judgment that equitable relief was warranted. ${ }^{48}$

42. See H.R. Conf. Re.p. No. 105-599, at 254 (stating there can be no relief where tax was shown on joint return, but not paid with return).

43. To be precise, a traditional relief requires that there be an understatement, and proportionate relief requires that there be a deficiency. For purposes of this Article, an understatement and a deficiency have the same definition.

44. See H.R. Conf. Rep. No. 105-599, at 254-55 (1998).

45. See Rev. Proc. 2003-6, 2003-32 I.R.B. 296. Under the safe harbor, a spouse will ordinarily be relieved of liability for an underpayment if the following requirements are met: (1) at the time the return was filed, she did not know, or have reason to know, that the tax would be unpaid; (2) at the time relief is sought, she is divorced or legally separated from the other spouse, or they have been living apart from each other for twelve months; and (3) she would suffer economic hardship if relief were not granted. As under proportionate relief, tax avoidance or fraud will disqualify a spouse for relief. See id.

46. The listed relevant factors are (1) marital status; (2) economic hardship; (3) knowledge or reason to know; (4) nonrequesting spouse's legal obligation; (5) significant benefit; (6) compliance with income tax laws; (7) abuse; and (8) mental or physical health. See id.

47. See, e.g., Weight v. Comm'r, 86 T.C.M. (CCH) 98 (2003) (holding petitioner proportionately liable for her 1996 federal income tax liability); Feldman v. Comm'r, 86 T.C.M. (CCH) 50 (2003) (attributing liability solely to husband); Collier v. Comm'r, 84 T.C.M. (CCH) 1799 (2002) (holding defendant failed to carry her burden of establishing other factors that weigh in favor of granting relief).

48. See Washington v. Comm'r, 120 T.C. 137 (2003) (holding that IRS abused discretion in denying relief under section $6015(\mathrm{f})$ ); Gay v. Comm'r, T.C. Summary Opinion 2003-36 (2003) (unpublished summary opinion) (holding petitioner was entitled to equitable relief); Ferrarese v. Comm'r, 84 T.C.M. (CCH) 400 (2002) (holding that IRS gave too much weight to taxpayer's knowledge of spouse's embezzled income); August v. Comm'r, 84 T.C.M. (CCH) 183, 186 (2002) (holding that IRS abused its discretion in denying section 6015(f) relief); Cheshire v. Comm'r, 115 T.C. 183, 199 (2000) (holding that IRS abused discretion in not granting section 6015 ( $f$ ) relief for penalties and additions to tax). 


\section{Tax Rationales for Joint and Several Liability}

As described in the previous part, current law imposes joint and several liability on married joint filers unless relief is available under the innocent spouse laws. This part examines the traditional rationales that have been offered for imposing joint and several liability on married joint filers.

\section{A. Marital Unity}

\section{Background}

The principal tax rationale for joint and several liability rests on the notion that a married couple is a single economic unit and, thus, a single taxpaying unit. The notion that a married couple is a single unit first appeared in 1921, quite early in the history of the joint return. ${ }^{49}$ At first, all it meant was that a husband's and wife's income and deductions were aggregated in determining the tax liability of each, sometimes to the benefit of taxpayers, as when a husband was permitted to use his wife's losses to decrease his taxable income, and sometimes to their detriment, as when a husband's and wife's incomes were aggregated and taxed at a higher rate under the progressive rate structure. ${ }^{50}$ Soon, however, marital unity was invoked to support the claim that each spouse should be liable for the entire tax relating to a joint return. ${ }^{51}$

Surprisingly, when Congress explicitly imposed joint and several liability on joint return filers in $1938,{ }^{52}$ it did not cite marital unity as its justification. Instead, the legislative history refers somewhat cryptically to "administrative reasons" and the "privilege of filing such joint returns" as the rationale for joint and several liability. ${ }^{53}$ Nonetheless, marital unity has come to be viewed as the principal rationale for the joint return and,

49. The joint return was first authorized in 1918. See Beck, supra note 6, at 335-47 (explaining Revenue Act of 1918). In 1921, the government argued that a joint return should be "treated as the return of a taxable unit . . a as though the return were that of a single individual." Op. Solicitor 90, 4 C.B. 236, 238 (1921).

50. See Op. Solicitor 90, 4 C.B. 236, 238 (1921) ("In cases, therefore, in which the husband or wife has allowable deductions in excess of his or her gross income, such excess may, if a joint return is filed, be deducted from the net income of the other for the purpose of computing both the normal and surtax."); see also Beck, supra note 6 , at 335-36 (same).

The government attempted to change its earlier position and argued for separate taxpayer treatment when doing so would increase the tax due. See, e.g., Article 117-5 of Regulation 86 (1935) (disallowing deduction of one spouse's capital losses against capital gains of the other spouse). But see Helvering v. Janney, 311 U.S. 189 (1940) (invalidating Article 117-5); see also, Beck, supra note 6, at 337-38.

51. See I.T. 1575, II-1 C.B. 144 (1923) (husband and wife "are individually liable for the full amount of tax shown to be due on a joint return" because "a single joint return is one return of a taxable unit").

52. See Revenue Act of 1938, ch. 289, $\$ 51$ (b), 52 Stat. 447, 476.

53. H.R. REP. No. 1860, 75th Cong. (3d Sess. 29-30 1938), reprinted in 1939-1 C.B., pt. 2, at 728, 749. These other rationales for joint and several liability are discussed below. See infra notes $67-71$ and accompanying text. 
with it, joint and several liability. ${ }^{54}$ The following paragraphs briefly trace the development of this fiction as the centerpiece for our tax treatment of married couples.

\section{The Fiction of Marital Unity ${ }^{55}$}

The concept of marital unity appeared in 1921, shortly after the inception of the joint return, but it did not begin to evolve into orthodoxy until the tax law changes of 1948. It was at this time that Congress created an income-splitting scheme, which allowed husbands ${ }^{56}$ residing in common law states to shift one-half of the income they earned to their wives for tax purposes. Under a progressive tax rates structure, this had the effect of reducing their tax burden. ${ }^{57}$ Prior to 1948 , only husbands residing in community property states could take advantage of income splitting. The political motivation for the 1948 tax law change was to procure for husbands in common law states the lower tax burden enjoyed by their counterparts in community property states, thus rendering meaningless for tax purposes the stronger property rights of women in community property states and quelling the movement towards adoption of community property laws. ${ }^{58}$ The camouflage for the political motivation was the unfounded assertion that a married couple is a single unit and that equalincome marital units should bear the same tax burden no matter what their state of residence..$^{59}$

The fiction of marital unity was also relied upon to amend the estate tax laws in 1948. As with the income tax changes, the estate tax laws were changed to reduce the tax burden of husbands residing in common law states, thereby equalizing their tax burden with that of husbands in community property states. As with the income tax, the same political motivation was again at work, and again it was rationalized by the unconsidered proclamation that marital units of equal wealth ought to pay equal amounts of estate tax. ${ }^{60}$

54. See, e.g., Beck, supra note 6 , at 377 ("If joint liability can be justified at all, it is only through an appeal to some special economic nature of the marital relationship.").

55. The following account is based on Lily Kahng, Fiction in Tax, in TAXING AmericA (Mary Louise Fellows \& Karen Brown eds., 1996).

56. I use the term "husbands" because men were the dominant income earners and wealth holders at this time.

57. Instead of the husband's income being taxed at one progression through the rate brackets, half the husband's income was taxed at two progressions through those rate brackets.

58. See Kahng, supra note 55, at 26-32.

59. See id. at 28-30.

60. See id. at 32 (explaining that like income tax amendments, stated goal of estate tax amendments was to equalize tax burden on husbands in all states, but alleged goal "was even less plausible in the estate . . . context, given that 1942 Act equalized the estate and gift tax burden on community property states"). 
The estate tax story did not end in 1948, for lawmakers inadvertently had created a tax disincentive for dower, the time-honored pattern of wealth transmission in which women inherited only income, never capital. ${ }^{61}$ Ultimately, in 1981, the disincentive was removed and the privileged tax status of dower was restored. The explanation for doing so should not be surprising at this point-marital unity. ${ }^{62}$

That marital unity was a convenient fiction, serving as political camouflage, was forgotten over the years. By 1976, marital unity had been elevated to a first principle of taxation, as evidenced by an observation of Professor Boris Bittker, one of the most influential tax scholars of the twentieth century: " $[T]$ he 1948 statutory principle of equal taxes for equalincome married couples has been 'almost universally accepted' by tax theorists . ..."63

\section{B. Other Tax Rationales}

The other tax rationales for joint and several liability are less significant than marital unity. This section presents them primarily for the sake of completeness.

\section{Administrative Convenience}

Administrative convenience is frequently cited as a reason for imposing joint and several liability. ${ }^{64}$ The argument is that because a husband's and wife's items of income, deduction, gain and loss are aggregated on a joint return, it is difficult or impossible to determine the separate tax liability of each. As Professor Richard Beck has pointed out, this problem could be remedied by eliminating aggregation and instead requiring each spouse to report separately his or her own items of income, deduction,

61. See id. at 33-34 ("The assumption underlying the marital deduction was mistaken in a crucial respect: husbands did not want to share their wealth with their wives. They wanted to retain control over their wealth through dower transfers, but dower transfers did not qualify for the marital deduction.").

62. See id. at 36-37 ("The legislative history of these provisions explains them by reference to the notion of the married couple as the taxpaying unit: all transfers within the unit should be exempt....").

63. Boris I. Bittker, Federal Income Taxation and the Family, 27 STAN. L. REv. 1389, 1395 (1975) (citation omitted).

64. The legislative history of the 1938 Act cites administrative convenience as one of the reasons for adopting statutory joint and several liability in 1938. See supra note 53 and accompanying text. The government also made, and lost, the argument for joint and several liability on the basis of administrative convenience in Cole v. Commissioner, 81 F.2d 485, 489 (9th Cir. 1935), a decision that was eventually reversed by the 1938 legislation. 
gain and loss on a dual-column joint return, as is done in several states. ${ }^{65}$ Segregating each spouse's tax items is not a difficult task. ${ }^{66}$

\section{Price for Tax Benefits of Joint Retum}

Another rationale given for joint and several liability is that it is the price married taxpayers must pay for the benefits they enjoy from filing a joint return. ${ }^{67}$ The principal benefit is a lower total tax liability than if the married couple filed separate returns. ${ }^{68}$ This rationale is implausible at best, as Professor Beck persuasively argues. He states three main responses to the price-for-benefits rationale: (1) the benefit that married couples receive from filing a joint return is variable and bears no reasonable relation to the burden of joint and several liability; (2) the "benefit" is sometimes actually a penalty in the form of a greater tax liability; and (3) the burden of joint and several liability often ends up being borne by the spouse who received little or no benefit from filing the joint return. ${ }^{69}$

\section{Inadequacy of Tax Rationales}

This part has argued that the most plausible tax rationale for imposing joint and several liability - the notion that husband and wife are a single taxpaying unit-is a fiction. The other rationales for joint and several liability are unpersuasive. Given the inadequacy of these rationales, one might conclude that a married individual, like any other individual, should be liable for taxes relating to his or her own activities and investments, and not those of any other person. ${ }^{70}$ The fiction of marital unity,

65. See Beck, supra note 6, at 389-90 (explaining different ways states tax spouses); see also Christian I, supra note 6, at 559-63 (discussing administrative necessity rationale for joint and several liability).

66. This is demonstrated by those states using a dual-column joint return. It is further demonstrated by both the prior law and the current law in federal innocent spouse provisions, both of which require that items giving rise to deficiency be allocated to one spouse or the other.

67. See Cole, 81 F.2d at 487 ("[R]espondent contends that by reason of electing to report their income for 1929 in a joint return, a privilege which the statute grants to married persons, petitioner and his wife must . . . be treated as one .... [W]e held against the respondent's contention.").

68. Another benefit is the administrative convenience of aggregating items of income, deduction, gain and loss.

69. See Beck, supra note 6 , at 369-77 (asserting that policy reasons for imposing joint and several liability on joint return filers are "obscure at best").

70. Several commentators have proposed that joint and several liability be abolished, thereby eliminating the need for any relief provisions such as the innocent spouse rules. See Beck, supra note 6, at 408; Jerome Borison, Alice Through a Very Dark and Confusing Looking Glass: Getting Equity from the Tax Court in Innocent Spouse Cases, 30 FAM. L.Q. 123, 171 (1996); Christian I, supra note 6, at 615-17; Martha W. Jordan, The Innocent Spouse Problem: Defining a Proportionate Solution, 24 OHio N.U. L. Rev. 517, 550 (1998).

More broadly, others have proposed eliminating the joint return, along with joint and several liability, and adopting mandatory separate return filing. See Pamela B. Gann, Abandoning Marital Status as a Factor in Allocating Income Tax Bur- 
however, is so deeply embedded in our tax system that joint and several liability is highly unlikely to be completely abolished. In addition, joint and several liability is not unique to tax law. It is imposed in many other contexts, which may provide guidance in determining whether joint and several tax liability can be justified. The next part examines non-tax rationales for joint and several liability, with a view toward their possible applicability to the tax treatment of married individuals.

\section{Non-tax Rationales for Joint and Several Liability}

This part briefly examines the rationales in other areas of law where liability is imposed on more than one individual. The liability might be joint and several, as in tort law, or it might be liability imposed on an individual for harms caused by another individual, as in vicarious liability, or it might be liability imposed on an individual for the debt or obligation of another, as in transferee liability.

\section{A. Tort Rationales}

Joint and several liability first developed in the area of tort law and was originally imposed where two or more individuals acted in concert to cause a harm or where they breached a common duty owed to the plaintiff. ${ }^{71}$ The scope of joint and several liability was gradually expanded to include situations where multiple tortfeasors contributed to a single harm, ${ }^{72}$ although in recent years it has been quite dramatically limited. ${ }^{73}$ Three rationales are commonly given for imposing joint and several liability in the context of multiple tortfeasors contributing to a single harm.

\section{Faimess}

One rationale for imposing joint and several liability on multiple actors contributing to a single harm is that it increases the likelihood that

dens, 59 Tex. L. Rev. 1, 39 (1980); Marjorie E. Kornhauser, Love, Money, and the IRS: Family, Income-Sharing, and the Joint Income Tax Return, 45 HASTINGS L.J. 63, 108-09 (1993).

71. See W. Page Keeton et al., Prosser and Keeton on the Law of Torts $\S 46$, at 322-23 (5th ed. 1984) (defining "concerted action").

72. See id. $\S 47$, at 328-29 (defining "entire liability").

73. A majority of states have curtailed joint and several liability. See Jonathan Cardi, Note, Apportioning Responsibility to Immune Nonparties: An Argument Based on Comparative Responsibility and the Proposed Restatement (Third) of Torts, 82 IowA L. REv. 1293, 1303-04 nn.54-55 (1997) (listing thirty-six states that have abolished, modified or limited joint and several liability). The Restatement (Third) of Torts also moved substantially away from joint and several liability towards proportionate liability. See Frank J. Vandall, A Critique of the Restatement (Third), Apportionment as It Affects Joint and Several Liability, 49 EMORY L.J. 565, 619-22 (2000) (arguing Restatement has overstepped bounds in rewriting law). The retrenchment of joint and several liability is one of numerous tort law changes growing out of the economic and insurance-related analysis of tort law. See generally George Priest, Economics of Civil Justice Reform Proposals, 9 Kan. J.L. \& Pub. Pol'y 401 (2000) (discussing justifications for "substantive civil justice reform proposals"). 
the plaintiff will be fully compensated for the harm suffered. ${ }^{74}$ The plaintiff is free to proceed against, and can recover from, any or all defendants. ${ }^{75}$ Another way that this rationale is sometimes articulated is that joint and several liability shifts the risk of an insolvent defendant from the plaintiff to the other defendants. ${ }^{76}$ In either case, the idea is that the plaintiff, being the innocent victim, should be given the best chance for full compensation, leaving the defendants, all of whom are wrongdoers, to seek an appropriate allocation of damages among themselves through the doctrine of contribution. ${ }^{77}$

74. See KeETON ET AL., supra note 71, at 330-32 (explaining judgment and satisfaction); David B. Spence, Imposing Individual Liability as a Legislative Policy Choice: Holmesian "Intuitions" and Superfund Reform, 93 Nw. U. L. REv. 389, 400 (1999) (explaining purpose of joint and several liability); Richard W. Wright, Allocating Liability Among Multiple Responsible Causes: A Principled Defense of Joint and Several Liability for Actual Harm and Risk Exposure, 21 U.C. DAvis L. REv. 1141, 1142-43 (1988) (explaining negative consequences of proportionate several liability and positive consequences of joint and several liability).

75. See Cardi, supra note 73, at 1301 (explaining defendant has burden of distributing fault to others, not plaintiff); see also Michael Green \& William Charles Power, Jr., Apportionment of Liability, 10 Kan. J.L. \& Pub. POL'y 30, 37 (2000) (explaining plaintiff's remedy).

76. See Kenneth S. Abraham, Individual Action and Collective Responsibility: The Dilemma of Mass Tort Reform, 73 VA. L. REv. 845, 862 (1987) (discussing effects of shifting burden to defendant); Wright, supra note 74 , at 1142-43 (asserting that placing burden on defendant creates chance of insolvency).

77. See Douglas F. Brennan, Joint and Several Liability for Generators Under Superfund: A Federal Formula for Cost Recovery, 5 UCLA J. ENvTL. L. \& PoL'y 101, 115 (1986) (explaining purpose of joint and several liability); Carol A. Mutter, Moving to Comparative Negligence in an Era of Tort Reform; Decisions for Tennessee, 57 TENN. L. REv. 199, 306 (1990) (explaining pros and cons of joint and several liability). Contribution was not always available among joint torffeasors, but became more prevalent in American courts as they expanded the application of joint and several liability. See KEETON ET AL., supra note 71, at 336-41 (detailing history of contribution); Lynda J. Oswald, New Directions in Joint and Several Liability Under CERCLA, 28 U.C. DAvis L. Rev. 299, 306-12 (1995) (explaining common law rule of joint and several liability).

Some commentators have argued that joint and several liability undermines, rather than promotes, fairness because it increases the risk that at least some defendants will end up paying more than their share of damages. See, e.g., Abraham, supra note 76, at 862 ("[T] he amount of liability imposed bears no necessary relation to the degree of responsibility of any particular defendant for the plaintiff's injury. In certain cases the amount of liability imposed may not even reflect the probability that a particular defendant is responsible at all."); Jerry L. Anderson, The Hazardous Waste Land, 13 VA. ENVTL. L.J. 1, 32-36 (1993) (explaining cost-sharing rationale is inadequate for hazardous waste clean up); John $\mathrm{C}$. Moorhouse et al., Law and Economics and Tort Law: A Survey of Scholarly Opinion, 62 Al.B. L. Rev. 667,679 (1998) (asserting joint and several liability is unfair because plaintiffs will sue those with "deep pockets"); Mutter, supra, at 314 (same); John W. Wade, Should Joint and Several Liability of Multiple Tortfeasors Be Abolished?, 10 AM. J. TRIAL Advoc. 193, 193 (1986) (same). 


\section{Difficulties of Determining Relative Fault}

Joint and several liability is also justified in situations where it is difficult or impossible to determine the relative fault of multiple wrongdoers. ${ }^{78}$ This is sometimes couched in terms of difficulty of ascertaining the causative role played by each wrongdoer. ${ }^{79}$ To some extent, the underlying policy goal here, as in "Fairness" above, seems to be to fully compensate the plaintiff, regardless of the allocation of blame among various defendants. ${ }^{80}$

\section{Deterrence}

In some contexts, joint and several liability is advocated to heighten deterrence of undesirable behavior by increasing the probability that at least some defendants will pay more than their proportionate share of damages. ${ }^{81}$ Whether joint and several liability in fact increases or de-

78. See Michael Hoenic, Products Liability: Substantive, Procedural and Policy Issues 191 (1992) ("At common law, the joint and several liability imposed upon joint tortfeasors was indivisible. Thus, any one of the joint tortfeasors was liable to the injured party for the entire damage."). But see Nancy L. Manzer, Note, 1986 Tort Reform Legislation: A Systematic Evaluation of Caps on Damages and Limitations on Joint and Several Liability, 73 CORNELL L. REv. 628, 643-46 (1988) (arguing it is unjust to make entity pay for another tortfeasor's faults).

79. See Restatement (Second) of Torts $\$ \$ 875,879$ (1979) (explaining that joint and several liability is imposed when the harm "cannot be apportioned" (section 879) or the harm is "single and indivisible" (section 875)); Richard W. Wright, Causation in Tort Law, 73 CAL. L. Rev. 1735, 1816-18 (1985) (noting difficulty in ascertaining causation with multiple tortfeasors); Richard W. Wright, The Logic and Fairness of Joint and Several Liability, 23 Memphis ST. U. L. Rev. 45, 59 (1992) (noting difficulty in ascertaining causation with separable injuries); Note, Joint and Several Liability for Hazardous Waste Releases Under Superfund, 68 VA. L. REv. 1157, 1187 (1982) (asserting joint and several liability in Superfund would give government flexibility to recover to fullest extent possible from defendants that can be identified).

80. See William K. Jones, Tort Triad: Slumbering Sentinels, Vicious Assailants, and Victims Variously Vigilant, 30 Hofstra L. Rev. 253, 290-91 (2001) ("If that harm is indivisible, and if it could have been avoided had care been taken by any one of the multiple defendants, then the fair share of each is $100 \%$."); John H. Wigmore, Joint Tortfeasors and Severance of Damages: Making the Innocent Party Suffer Without Redress, 17 ILL. L. REv. 458, 459 (1923) (giving example of unredressable party that cannot identify tortfeasor).

81. This is true for "deep pocket" defendants, from whom plaintiffs are more likely to seek full recovery, leaving such defendants to the expense and vagaries of seeking contribution from other defendants. See Larry Pressler \& Kevin V. Schieffer, Joint and Several Liability: A Case for Reform, 64 DENV. U. L. REv. 651, 652 (1988) ("[D] eep pocket defendants . . . are especially likely to be brought into a suit when it appears likely that the party most responsible for the harm is judgment proof.").

The argument that joint and several liability heightens deterrence is commonly made in the toxic tort context. See Brennan, supra note 77, at 114-15 (arguing that joint and several liability encourages responsible behavior); Anita $M$. D'Arcy, Note, Joint and Several Liability Under Superfund, 13 Loy. U. CHI. L.J. 489, 522 (1982) (asserting that joint and several liability may deter future improper disposal); David J. Engel, Note, Joint and Several Liability Under Superfund: The Plight of the Small Volume Hazardous Waste Contributor, 31 WAYNE L. REv. 1057, 1080 n.128 
creases deterrence, and whether either is desirable, is the subject of considerable debate. ${ }^{82}$

\section{B. Agency Rationales}

Another area of law where liability is imposed on more than one individual is agency law. Liability is vicarious-one individual (the principal) is held liable for the actions of another individual (the agent) by virtue of the principal's relationship with the agent. ${ }^{83}$ Under certain circumstances, a principal may be liable for an agent's tortious conduct or may be bound by contractual obligations entered into by the agent. ${ }^{84}$ The legal definition of the principal/agent relationship is a "fiduciary relation which results from the manifestation of consent by one person to another that the other shall act on his behalf and be subject to his control." 85 Economists define the agency relationship as one in which the principal employs or contracts with the agent and does not directly control the agent. ${ }^{86} \mathrm{Re}$ lationships that typically result in the imposition of vicarious liability include: principal/agent, employer/employee and partner/partner. ${ }^{87}$ The

(1985) (stating that joint and several liability gives industries incentive to reduce production of waste and to dispose of waste properly).

82. Compare William M. Landes \& Richard A. Posner, The Economic Strug TURE OF TORT LAW 193 (1987) (noting that joint and several liability may be more effective deterrent), and Lewis A. Kornhauser \& Richard L. Revesz, Sharing Damages Among Multiple Tortfeasors, 98 YALE L.J. 831, 833 (1989) (asserting that joint and several liability may be more efficient under some circumstances), and William M. Landes \& Richard A. Posner, Joint and Multiple Tortfeasors: An Economic Analysis, 9 J. Legal STUd. 517, 529-31 (1980) (discussing contribution in joint and several liability), with Gerald W. Boston, Toxic Apportionment: A Causation and Risk Contribution Model, 25 ENvTL. L. 549, 570-71 (1995) (explaining joint and several liability may result in over- or under-deterrence), and Daniel C. Esty, Toward Optimal Environmental Governance, 74 N.Y.U. L. REv. 1495, 1525 (1999) (stating that Superfund's joint and several liability has resulted in sub-optimal cleanup efforts and site abandonment), and Landes \& Posner, supra, at 543 (arguing that joint and several liability, coupled with contribution, results in high administrative costs), and Kathryn E. Spier, A Note on Joint and Several Liability: Insolvency, Settlement, and Incentives, $23 \mathrm{~J}$. LEGAL STUd. 559, 560 (1994) ("The excessive value that the plaintiff derives from settlement will induce the defendants to over invest in precautions ex ante . ..."), and Aaron D. Twerski, The Joint Tortfeasor Legislative Revolt: A Rational Response to the Critics, 22 U.C. Davis L. Rev. 1125, 1127 (1989) (asserting joint and several liability accentuates and exacerbates all imperfections in present tort compensation system). See generally Moorhouse et al., supra note 77, at 678-79 (describing both sides).

83. A principal may also be liable by virtue of the principal's own actions, but this type of liability is generally excluded from the definition of vicarious liability.

84. See generally Restatement (Second) of AgenCy chs. 6, 7 (1958) (discussing principal liability to third persons).

85. Id. 1 (1958).

86. See Lewis A. Kornhauser, An Economic Analysis of the Choice Between Enterprise and Personal Liability for Accidents, 70 CAL. L. REv. 1345, 1346-47 (1982); Alan O. Sykes, The Economics of Vicarious Liability, 93 YALE L.J. 1231, 1231 (1984).

87. Particularly in recent years, commentators have argued for the extension of vicarious liability to other relationships. See, e.g., Valerie D. Barton, Comment, 
rationales for vicarious liability can be grouped into two categories: fairness and efficiency.

\section{Faimess}

One rationale for vicarious liability is that it is fair or just. According to Judge Friendly, vicarious liability rests "in a deeply rooted sentiment that a business enterprise cannot justly disclaim responsibility for accidents which may fairly be said to be characteristic of its activities." 88 Another formulation of the fairness rationale for vicarious liability is that it offers more adequate compensation for victims, while distributing costs among those who have benefited from the activities giving rise to the harm. ${ }^{89}$ Other, more complex fairness rationales include one based on reciprocity of risk and another based on a corrective justice approach. ${ }^{90}$

\section{Deterrence/Efficiency}

Another rationale for vicarious liability is creating an incentive for an individual to monitor or supervise the actions of another. The underlying premise is that the individual with the supervisory duty, by virtue of his relationship with the wrongdoer, is in a position to prevent the harm committed by the wrongdoer. ${ }^{91}$ A related rationale for vicarious liability is that under certain circumstances it is efficient-that is, it deters socially undesirable behavior or optimizes societal allocation of resources in a cost-effective manner, by, for example, minimizing transaction costs or spreading the risk of loss. ${ }^{92}$

Reconciling the Burden: Parental Liability for the Tortious Acts of Minors, 51 EMORY L.J. 877,880 (2002) (advocating parent-child vicarious liability in wake of Columbine High School shooting); Barbara A. Micheels, Comment, Is Justice Served? The Development of Tort Liability Against the Passive Parent in Incest Cases, 41 ST. Louls U. L.J. 809, 810-11 (1997) (advocating liability for "innocent" spouse who permitted other spouse to abuse child); Michele M. O'Malley, Comment, The Misapplication of Comparative Negligence: An Argument for the Use of Joint and Several Liability in Gun Control, 40 WASHBURN L.J. 334, 335 (2001) (advocating use of joint and several liability if child negligently injures another using parents' gun); Richard Smith, Note, A Comparative Analysis of Dramshop Liability and a Proposal for Uniform Legislation, 25 IowA J. CORP. L. 553, 574-76 (2000) (advocating dramshop liability for accidents resulting from improper sale of alcohol). 1968).

88. Ira S. Bushey \& Sons, Inc. v. United States, 398 F.2d 167, 171 (2d Cir.

89. See Gregory C. Keating, The Idea of Fairness in the Law of Enterprise Liability, 95 Mich. L. REv. 1266, 1356 (1997) ("The choice between negligence and enterprise liability is a choice between leaving a grave and underserved misfortune on the victim, and inflicting a far lesser burden on those who deserve to bear the costs.").

90. See Gary T. Schwartz, The Hidden and Fundamental Issue of Employer Vicarious Liability, 69 S. CAL. L. REv. 1739, 1749-54 (1996) (describing various fairness justifications for vicarious liability).

91. See Keeton et al., supra note 71 , at 346-48, 500-01 (discussing general aspects of and justification for vicarious liability).

92. See generally William M. Landes \& Richard A. Posner, The Economic STruCture OF TORT LAW 120-21 (1987) (explaining respondeat superior); STEven 


\section{Fraudulent Conveyance/Transferee Liability Rationales}

Under certain circumstances, if a debtor makes a fraudulent transfer of assets to a third party, a creditor can reach those assets to satisfy his debt. ${ }^{93} \mathrm{~A}$ fraudulent transfer is one made with the intent to hinder, delay or defraud a creditor. ${ }^{94}$ Actual fraud can be established indirectly by factors such as: (1) the existence of a familial or agency relationship between the transferor and the transferee; (2) the concealment of the transfer from creditors; (3) the receipt by the transferor of property on exchange less valuable than that the transferor gave up; and (4) the transferor's poor financial condition or insolvency at or upon the transfer. ${ }^{95}$ In the absence of actual fraudulent intent, constructive intent may be found if the transfer was made without adequate consideration and the debtor either: (1) was insolvent at the time of the transfer; (2) became insolvent as a result of it or was thinly capitalized; or (3) did not intend not to pay his debts as they became due. ${ }^{96}$ Fraudulent conveyance law was originally grounded in fairness rationales, but more recently efficiency justifications have also been developed.

\section{Faimess/Morality}

One rationale for fraudulent conveyance law is that a debtor has a moral obligation not to make gifts while insolvent. ${ }^{97}$ This rationale is also couched in fairness terms: a debtor has the duty to be fair to all credi-

ShaVEll, ECONOMIC ANALYSIS OF ACCIDENT LAW 170-75 (1987) (discussing vicarious liability); Kornhauser, supra note 86 , at $1346-47$ (discussing rationales for enterprise liability); Alan O. Sykes, The Boundaries of Vicarious Liability: An Economic Analysis of the Scope of Employment Rule and Related Legal Doctrines, 101 HARv. L. REv. 563, 565-70 (1988) (discussing efficiency of vicarious liability in employment relationship); Sykes, supra note 86 , at 1235-36 (discussing risk efficiency in agency liability).

93. See Elizabeth Warren \& Jay Westbrook, The Law of Debtors and CrediTORs 138-40 (2d ed. 1992) (discussing development of Uniform Fraudulent Transfer Act).

94. See Peter Alces, The Law of Fraudulent Transactions $§ 7: 4$ (1989) (explaining requirements of fraudulent transfers).

95. Unif. Fraudulent Transfer Act $\$ \S 4(\mathrm{~b})(1),(2),(4),(8)$ (1984); see also Frank R. Kennedy, The Uniform Fraudulent Transfer Act, 18 UCC L.J. 195, 200-08 (1986) (discussing specific requirements for fraud under UFTA); Louis J. Vener, Transfers in Fraud of Creditors Under the Uniform Acts and the Bankruptcy Code, 92 Com. L.J. 218, 222-42 (1987) (explaining general requirements of fraud).

96. Unif. Fraudulent Conveyances Act $\$ \S 4-8$ (1918); see also John C. McCoid II, Constructively Fraudulent Conveyances: Transfers for Inadequate Consideration, 62 TEx. L. REv. 639, 656-57 (1983) (discussing factors associated with constructive intent to defraud).

97. See Robert C. Clark, The Duties of the Corporate Debtor to Its Creditors, 90 HaRv. L. Rev. 505, 509-11, 544 (1977) (explaining debtors' moral obligation to give primary consideration to legal obligations over personal interests and further explaining creditors' fundamental right to expect insolvent debtors not to make transfers). 
tors. ${ }^{98}$ Also, the purpose of fraudulent transfer law is to prevent unjust depletion of the debtor's estate to the detriment of creditors. ${ }^{99}$

\section{Efficiency}

The other rationale for fraudulent conveyance law is based on efficiency. Professors Douglas Baird and Thomas Jackson's influential article was one of the first to conduct an efficiency analysis of fraudulent conveyance law. Starting with the proposition that " $[t]$ he ambition of . . f fraudulent conveyance law, should provide all the parties with the type of contract that they would have agreed to if they had had the time and money to bargain over all aspects of their deal," they conclude that the scope of fraudulent conveyance law should be a quite limited one, applying to invalidate only sham transactions and gratuitous transfers. ${ }^{100}$ Other commentators, explicitly adopting an efficiency perspective, have since argued for a broader scope for fraudulent conveyance laws. ${ }^{101}$

\section{Evaluation of Current Law}

This part evaluates the current law treatment of married couples filing jointly by reference to the rationales for joint and several liability described in Part IV.

\section{A. Traditional Relief}

The elements of traditional relief that are relevant to this analysis are (1) that there be an understatement of tax attributable to erroneous items of the other spouse; (2) that the spouse seeking relief did not know, and had no reason to know, that there was an understatement; and (3) it is inequitable to hold the spouse seeking relief liable for the deficiency in tax attributable to this understatement. ${ }^{102}$ All of these elements must be met in order for a spouse not to be held jointly and severally liable. For purposes of this analysis, it is useful to restate the rules in terms of the conditions under which the spouse will be liable. Accordingly, a spouse is

98. See Frank R. Kennedy, Involuntary Fraudulent Transfers, 9 CaRdozo L. Rev. 531,534 (1987) (explaining that fraudulent transfer rules developed to allow creditors to enforce duty of debtor to be fair to all creditors).

99. See Jack F. Williams, Revisiting the Proper Limits of Fraudulent Transfer Law, 8 BANKr. Dev. J. 55, 59 (1991) (noting that most commentators agree fraudulent transfer law exists to prevent unjust diminution of debtor's estate).

100. See Douglas G. Baird \& Thomas H. Jackson, Fraudulent Conveyance Law and Its Proper Domain, 38 Vand. L. Rev. 829, 835-36, 840 (1985) (discussing purpose and appropriate scope of conveyance law).

101. See Marie T. Reilly, The Latent Efficiency of Fraudulent Transfer Law, 57 LA. L. REv. 1213, 1251 (1997) (advocating efficiency justifications for fraudulent transfer law); Kathryn V. Smyser, Going Private and Going Under: Leveraged Buyouts and the Fraudulent Conveyance Problem, 63 IND. L.J. 781, 784 (1988) (discussing creditors' rights in leveraged buyouts); Williams, supra note 99, at 127-28 (discussing problems with modern fraudulent transfer law).

102. See supra notes $14-19,27-29$ and accompanying text. 
liable if (1) the understatement is attributable to her erroneous items, or

(2) she knew, or had reason to know, that there was an understatement, or

(3) it would not be inequitable to hold her liable. This third condition will be further restated in terms of significant benefit-the factor that courts have found to be the most important in determining whether the equity condition is met. Thus, under the third condition of liability, a spouse will be held liable if she significantly benefited from the understatement. ${ }^{103}$

\section{Tort Rationales}

The tort rationales for joint and several liability posit that there are multiple wrongdoers who have contributed to a single harm to a victim. A threshold problem in applying the tort rationales in the tax context relates to the identity of the wrongdoers. As applied in the tax context, the harm is the failure to accurately report and pay a tax liability. The victim is either the government, or more generally, all other taxpayers, who will have to pay more in taxes to make up the revenue shortfall. Identifying the wrongdoer(s) in the tax context is more difficult. It begs the question to assert that both husband and wife are responsible for the tax, and that, therefore, they are both wrongdoers if the tax is not reported and paid. The underlying question is who should be responsible for the tax?

A basic principle of taxation is that each individual ought to be responsible for the tax relating to his or her income-producing activities or investments. As I have argued above, the fiction of marital unity does not warrant modifying this basic principle. The first element under traditional relief-which essentially imposes liability for any taxes relating to the activities of the spouse seeking relief-is consistent with this approach and splinters the marital unit, underscoring the artificiality of the construct. Each married individual is a "wrongdoer" with respect to tax liabilities relating to her own activities, just as each unmarried individual is.

Even if one views both spouses as wrongdoers contributing to the harm, the tort rationales for joint and several liability are ill-fitted to the tax context. The three tax rationales for joint and several liability are (1) fairness to the victim, (2) difficulties in ascertaining each wrongdoer's contribution to the harm and (3) heightened deterrence.

\section{a. Fairness to Victim}

The fairness rationale assumes blameworthy wrongdoers and a victim who deserves full compensation. In the tax context, the fairness rationale loses force because the failure to report and pay taxes does not inflict significant harm on any particular individual. Moreover, in the tax context, it does not seem particularly unfair that the victim (the government) should bear the burden of collection and the risk of insolvency. The gov-

103. See supra notes $24-26$ and accompanying text. 
ernment-as-victim is not lacking in resources to pursue compensation for the harm, nor is it likely to suffer unduly if one or more of the wrongdoers turns out to be insolvent. Indeed, one of the common complaints about imposing joint and several liability in the tax context is that the government has superior collection capabilities and a greater ability to absorb the risk of loss and should not be permitted to shift these burdens to a spouse who is left only with unenforceable contribution rights against the other spouse. ${ }^{104}$

\section{b. Difficulties of Determining Relative Fault}

The second tort rationale, that it is difficult to ascertain each individual's contribution to the harm, also applies poorly in the tax context. Under traditional relief, each spouse's contribution to the harm-that is, the failure to report and pay tax-is quite clear. There are two possibilities: (1) the understatement of tax is related to the activities of the spouse seeking relief or (2) the understatement is related to the activities of the other spouse.

If the understatement of tax is related to the activities of the spouse seeking relief, she is liable. In this case, she causes the harm by, for example, failing to report income from services she performed or property she owned, or by claiming overstated or spurious deductions related to a business she conducted. If, on the other hand, the understatement is related to the other spouse's activities, she is liable either if she knew, or had reason to know, of the understatement, or if she significantly benefited from the understatement, or both.

In the tax setting, then, it is relatively easy to ascertain each spouse's role in producing the harm. Compare this to the paradigm tort case for joint and several liability: two defendants shoot towards the plaintiff with shotguns; only one pellet hits and injures the plaintiff, but it cannot be ascertained which defendant caused the injury. ${ }^{105}$

104. See Beck, supra note 6 , at $324-32$ (discussing unfairness of joint liability); Christian I, supra note 6, at 588-92 (discussing difficulties faced by aggrieved spouses).

105. Summers v. Tice, 199 P.2d 1, 5 (1948) (holding both defendants liable). The analysis of the causative role played by each spouse highlights another fundamental problem in relying on the tort rationales to justify joint and several liability in the tax context. It is clear that when an understatement relates to the activities of the spouse seeking relief, she has caused the understatement by engaging in the activities and failing to accurately determine their tax consequences. When the understatement relates to the activities of the other spouse, however, her actions consist of knowing, or having reason to know, of her spouse's activities, or significantly benefiting from the understatement of tax. Neither of these actions appears to cause the understatement. To return to the paradigm tort case, it would be as if one defendant were held jointly and severally liable for the shotgun injury to the plaintiff because he knew the other defendant fired the shotgun towards plaintiff, or because the injury suffered by the plaintiff allowed the first defendant to shoot a duck the plaintiff would otherwise have shot. 


\section{c. Deterrence}

Increased deterrence is the third tort rationale for imposing joint and several liability. In general, deterrence is not a principal goal of the tax system; on the contrary, its goal is to raise revenue while affecting behavior as little as possible. ${ }^{106}$ The tax system does have a deterrent aspect, however. It is designed to deter individuals from failing to report and pay tax on income they produce. Monitoring for compliance is accomplished by audits and other enforcement devices, and the penalties for noncompliance include any tax liability owed along with interest charges and penalties. In this way, taxes act as penalties intended to deter the behavior of noncompliance. ${ }^{107}$

The obligations to report and pay taxes-along with the penalties imposed in order to deter noncompliance with these obligations-are generally imposed on the individual whose activities produce the income. Imposing the duty to pay the tax on the individual producing the income comports with the fundamental idea of imposing tax burdens based on the ability to pay. Requiring that the individual also report the tax makes sense because he or she knows about the income-producing activities. Of course, the individual has an incentive not to comply with these obligations. ${ }^{108}$ Compliance is sometimes enhanced by imposing these obligations on additional parties through information reporting and wage withholding. ${ }^{109}$

106. A tax is more in the nature of a charge for government-provided goods or services or a contribution for public goods than a behavior-deterring penalty.

107. The standard economic model of deterrence has been applied to tax compliance. The model was developed by Michael G. Allingham \& Agnar Sandmo, Income Tax Evasion: A Theoretical Analysis, 1 J. PuB. Econ. 323 (1972), and is based on Gary Becker's model of criminal enforcement. See Gary S. Becker, Crime and Punishment: An Economic Approach, 76 J. Pol. ECON. 169, 172 (1968) (discussing optimal deterrence); see also, e.g., Graeme S. Cooper, Analyzing Corporate Tax Evasion, 50 TAX L. REv. 33, 49-50 (1994) (discussing role of criminal law in determining taxpayer compliance); Mark P. Gergen, The Logic of Deterrence: Corporate Tax Shelters, 55 TAx L. REv, 255, 274-82 (2002) (discussing potential deterrence of corporate tax shelters); Eric A. Posner, Law and Social Norms: The Case of Tax Compliance, 86 VA. L. REv. 1781, 1787-88 (2000) (discussing penalty aspect of taxes).

108. See Joshua D. Rosenberg, The Psychology of Taxes: Why They Drive Us Crazy, and How We Can Make Them Sane, 16 VA. TAX ReV. 155, 188-97 (1996) (discussing taxpayers' financial incentive to underestimate income and overstate deductions furthered by low risk of getting caught and infrequent penalty enforcement if caught).

109. See, e.g., I.R.C. $§ 6041$ (2003) (wage reporting); id. $\$ \S 6042,6049$ (2003) (dividend and interest reporting); id. $\$ 3401$ (2003) (wage withholding). These compliance mechanisms have greatly increased compliance. See, e.g., M. Bernard Aidinoff et al., ABA Commission on Taxpayer Compliance, Report and Recommendations on Taxpayer Compliance, 41 TAX LAw. 329, 349 (1987) (discussing costs and benefits of compliance measures); Gene Steurele, The Tax Gap, 72 TAx Notes $1187,1187-88$ (1996) (concluding that reducing opportunity to escape detection through withholding and third-party reporting reduces noncompliance). 
Information reporting obligations are imposed on those who, like the taxpayer himself, have knowledge of the item they are required to report, for example, in the case of a bank that pays interest to the taxpayer or an employer who pays wages to the taxpayer. The penalties for failure to report are relatively low-generally $\$ 50$ per violation, subject to overall yearly limitations ${ }^{110}$ - presumably because the third parties have little disincentive not to comply. ${ }^{111}$

Withholding obligations are imposed on those who are the source of payments made to taxpayers. The payor withholds and remits amounts to government as advance payments of the taxpayer's tax liability. ${ }^{12}$ The penalties for noncompliance are high-one hundred percent of the amount required to be withheld and remitted ${ }^{13}$ - presumably to deter the payor from diverting the withheld amounts for his own benefit rather than remitting them to the government. ${ }^{114}$ Within the deterrence scheme of the tax system, information reporting and wage withholding are instances where compliance is enhanced by imposing obligations to report or pay on parties other than the taxpayer. ${ }^{115}$ Spousal liability might be justified as a similar means of enhancing compliance, but upon closer examination, the parallels prove to be superficial.

Like a bank who pays interest to a taxpayer, the spouse of a taxpayer may have information that, if reported, would increase compliance by the taxpayer. One could argue that imposing liability on her for failure to report this information has the effect of imposing on her a duty to report and that the duty is imposed in order to increase the taxpayer's compliance. Nevertheless, a spouse's obligation to report, such as it is, ${ }^{116}$ differs in significant ways from the bank's.

110. See I.R.C. $\$ \$ 6721-24$ (2003).

111. Their principal disincentive is the administrative cost of reporting.

112. Withheld amounts are deemed held in trust for the benefit of the United States. See I.R.C. $§ 7501$ (2003).

113. See I.R.C. $\$ 3403$ (2003) (responsibilities); id. $\$ 6672(a) \quad$ (2003) (penalties).

114. Commentators have questioned whether the penalties should be so severe and so broadly applied, but no one has questioned their efficacy. See Mary A. Bedikian, The Pernicious Reach of 26 U.S.C. Section 6672, 13 VA. TAX Rev. 225, 230-31 (1993) (surveying commentators' views on personal tax penalties for corporate officers); Gerald P. Moran, Willfulness: The Inner Sanctum or Unnecessary Element of Section 6672, 11 U. TOL. L. REV. 709, 713 (1980) (noting penalty's "economic harshness" and "severity"); Stephen J. Vasek, The Hidden Tax Trap of I.R.C. Section $6672,67 \mathrm{KY}$. L.J. 27, 73 (1978) ("Applications of section 6672, as currently interpreted, often impose a harsh penalty on morally innocent and unsuspecting business managers."); David M. Walker, The Section 6672 100\% Penalty: How to Avoid Going Down with the Ship, 46 TAX LAw. 801 (1993) (comparing code penalty provision to Bermuda Triangle).

115. This is not exactly analogous to the tort rationale for joint and several liability. There, deterrence is not used as a rationale for imposing liability, but rather as a rationale for making liability joint and several.

116. Of course, unlike the bank, she does not have an explicit obligation to report, except insofar as she signs the joint return. Her putative reporting duties 
First, under traditional relief, she is obligated only to report information of which she has knowledge or reason to know. This suggests a further duty to investigate, which is borne out by the courts' interpretation of the "reason to know" requirement. ${ }^{17}$ While the duty to investigate may at first blush seem unobjectionable, when stated in terms of the deterrence framework, it is less innocuous: to increase the taxpayer's compliance, the spouse has a duty to investigate those activities, and to report her findings to the IRS. The spouse is forced to step into the shoes of an auditor, a role that is wildly incongruent with the love, intimacy and trust usually associated with the marital relationship. ${ }^{118}$

A second problem with analogizing spousal liability to information reporting is the magnitude of the penalty imposed on the spouse. While a bank incurs a $\$ 50$ penalty for failure to report, the spouse incurs a penalty equal to the tax liability relating to the information she failed to report, along with any interest charges and penalties. ${ }^{119}$ The spouse's penalty is seriously disproportionate when compared to the bank's. This becomes even more apparent when one considers the reporting "requirement" most comparable to the spouse's: friends, neighbors and co-workers of the taxpayer are rewarded if they provide information about the taxpayer to the IRS (the so-called "reward for rats" program); they are not penalized for failing to do so. ${ }^{120}$

With regard to the duty to pay, the analogy between third-party withholding agent and spouse is even more attenuated. Unlike an employer, the spouse does not have control of amounts paid to the taxpayer and, thus, does not have the opportunity to withhold before such control is transferred to the taxpayer. Furthermore, although the spouse may nominally have some control by reason of jointly owned assets, the spouse is not likely to have actual control over amounts earned by the taxpayer. ${ }^{121} \mathrm{Fi}-$

could be carried out by revising the return to reflect her information or by refusing to sign the return.

117. See supra note 21.

118. Cf. Malinda L. Seymore, Isn't It a Crime: Feminist Perspectives on Spousal Immunity and Spousal Violence, 90 Nw. U. L. REv. 1032, 1044-52 (1996) (surveying history of spousal immunity).

119. One could argue that a higher penalty must be imposed on the spouse than on a bank to overcome the spouse's inclination not to harm her husband, but this argument merely highlights the incongruity of requiring a spouse to inform on her husband.

120. See I.R.C. $\$ 7623$ (2003) (authorizing Secretary to pay sums necessary for detecting violations); Treas. Reg. $\$ 301.7623-1$ (2003) (authorizing rewards for information relating to tax code violations). The IRS paid out rewards of $\$ 1.8$ million (on 681 claims) in 1995, $\$ 3.4$ million (on 669 claims) in 1994 and $\$ 5.3$ million (on 829 claims) in 1993. Tom Herman, IRS Rewards to Informants Fell Sharply Last Year, WALl ST. J., Feb. 14, 1996, at A1. Even on this small scale, at least one lawmaker has argued that the reward program is a "negative way to collect funds." Statement of Senator Harry Reid, John C. Bell ed., Congressional Record: May 3-9, 79 Tax Notes 1015, 1016 (John C. Bell ed., 1998) (quoting Sen. Harry Reid, D-Nev).

121. See Kornhauser, supra note 70, at 105-06 (finding that substantial numbers of couples separate some or all of their income). 
nally, even if the spouse did have control, it would be incongruous with the marital relationship to impose on her the obligation to set aside funds for the benefit of the government.

\section{Agency Rationales}

The agency rationales for vicarious liability add little to the analysis of traditional relief thus far. A threshold problem is that spouses do not have a principal/agent relationship with each other, either in the legal sense of one being controlled by the other or in the economic sense of one contracting with the other. In some instances, an agency relationship has been found to exist between married persons. ${ }^{122}$ The marital relationship, however, differs from an agency relationship in significant ways. There are complex psychological, emotional and financial facets of marriage that are not present in an agency relationship. ${ }^{123}$

Even assuming that the spouse does control the taxpayer (by reporting information about the taxpayer to the IRS or diverting funds for the payment of taxes), the two rationales for imposing vicarious liability (fairness and deterrence) are problematic for the reasons described above. In brief, as between the spouse and government, it does not seem fair to impose the burden of collection on the taxpayer and the risk of his insolvency on the spouse. From a deterrence standpoint, imposing a collection duty on the spouse as a means of achieving greater compliance by the taxpayer interferes fundamentally with the marital relationship.

\section{Fraudulent Conveyance Rationales}

There are thematic similarities between fraudulent conveyance laws and the traditional relief innocent spouse rules. A classic fraudulent transfer might involve a debtor transferring assets to a family member, either as a gift or without adequate consideration, in order to avoid paying a creditor. Applying this template to spousal tax liability, one could view the taxpayer (debtor) as transferring assets to a family member (the spouse)

122. See, e.g., In re Tara of North Hills, 116 B.R. 455, 462 (E.D.N.C. 1989), affd, 904 F.2d 701 (4th Cir. 1990) (finding that wife acted as agent for husband); In re Paolino, 89 B.R. 453, 460 (Bankr. E.D. Pa. 1988) (discussing presumptive agency relationship between spouses).

123. See Robert B. Chapman, Coverture and Cooperation: The Firm, the Market, and the Substantive Consolidation of Married Debtors, 17 BANkr. Dev. J. 105, 177-80 (2000) (discussing various facets of marital relationship); A. Mechele Dickerson, To Love, Honor, and (Oh!) Pay: Should Spouses Be Forced to Pay Each Other's Debts?, 78 B.U. L. REv. 961, 965 (1998) (describing marriage as "a relationship involving at least some level of mutual emotional and economical support"); Steven $\mathbf{H}$. Resnicoff, Is It Morally Wrong to Depend on the Honesty of Your Partner or Spouse? Bankruptcy Dischargeability of Vicarious Debt, 42 CASE W. RES. L. REv. 147, 205 (1992) (arguing that marital relationship differs from agency relationship in significant ways: one spouse does not control the other, and there are complex psychological, emotional and financial facets of marriage that do not exist in agency relationship). 
without adequate consideration (as evidenced by significant benefit to the spouse) in order to avoid paying his creditor (the government).

The parallels exist, but there are differences as well. One important difference is that fraudulent conveyance law focuses on the fraudulent intent (whether actual or constructive) of the debtor, while the traditional innocent spouse rules completely disregard the taxpayer's intent. Another is that a fraudulent conveyance can involve a transfer to anyone-a family member, friend, another creditor-not just the debtor's spouse. It is beyond the scope of this Article to analyze all of the ways in which fraudulent conveyance law diverges from the traditional innocent spouse rules. Nor would it be productive to do so, for the Internal Revenue Code has a separate fraudulent conveyance statute ${ }^{124}$ and does not need another one in the guise of innocent spouse relief. ${ }^{125}$

In summary, the tort, agency and fraudulent conveyance rationales for imposing multiple liability do not satisfactorily explain or justify the traditional innocent spouse rules. Imposing liability on a spouse for an understatement attributable to her erroneous items is consistent with the fundamental principle that each individual is responsible for paying tax on the income arising from her activities. Where the understatement is attributable to the other spouse, however, liability should not be imposed on a spouse merely because she knows, or has reason to know, of the understatement or because she received a significant benefit from the understatement. These liability rules under traditional relief should be repealed.

\section{B. Proportionate Relief}

Proportionate relief allocates a deficiency between two spouses in proportion to their respective shares of erroneous items that gave rise to the deficiency. Under proportionate relief, a spouse is not liable if (1) the deficiency is allocable to the other spouse in proportion to his erroneous items; (2) the spouse seeking relief does not have actual knowledge of these items; and (3) she and the other spouse do not transfer assets to avoid taxes or engage in fraudulent schemes. ${ }^{126}$ Restating these as conditions under which she will be liable, she will be held liable (1) to the extent the deficiency is allocable to her in proportion to her erroneous items; or (2) if she had actual knowledge of the other spouse's erroneous items; or (3) if she and the other spouse sought to avoid taxes or acted fraudulently.

124. See I.R.C. $\$ 6901$ (2003).

125. See Beck, supra note 6 , at $402-08$ (discussing transferee liability as alternative to joint liability); Christian I, supra note 6 , at $572-78$ (advocating transferee liability as solution to problems with spousal joint liability).

126. A fourth requirement is that the spouse seeking request and the other spouse are divorced, legally separated or have lived apart for the twelve-month period preceding the date relief is requested. There is no plausible justification for this requirement. 
Much of the analysis of the traditional innocent spouse rules in Part V.A. can be applied here. Thus, the first condition of liability under proportionate relief-under which a spouse is liable to the extent the deficiency is attributable to her erroneous items-underscores each spouse's distinct identity as a taxpayer and supports the claim that marital unity is a fiction. In addition, the fairness arguments for imposing liability are not persuasive in the tax setting, where there is no identifiable victim and where, to the extent the government is the victim, its ability to absorb loss and its collection powers vastly outmatch those of the taxpayer's spouse.

Viewed from a deterrence standpoint, the proportionate relief rules differ from the traditional relief rules in that they impose spousal liability only if a spouse had actual knowledge of the other spouse's erroneous items, and not if she had reason to know of those items. In terms of compliance, the proportionate relief rules can be viewed as imposing on the spouse a duty to report what she knows, but arguably they do not impose the further duty to investigate. ${ }^{127}$ Imposing a duty to report is problematic for the reasons discussed above: such a duty is inconsistent with the marital relationship and the penalty for failure to do so is disproportionately high.

The third condition for proportionate relief imposes liability if assets were transferred by the other spouse to the spouse seeking relief with the principal purpose of tax avoidance, or if one or both spouses acted fraudulently. Like the significant benefit test under traditional relief, this condition for liability bears a resemblance to fraudulent conveyance law and, like the significant benefit test, it is unnecessary in view of the Internal Revenue Code's fraudulent conveyance law.

\section{Equitable Relief}

Equitable relief is a residual provision, providing relief in situations where traditional and proportionate relief are not available, but it would be inequitable to hold the spouse liable. There has been relatively little interpretation and application of this provision. ${ }^{128}$ In determining the scope of the provision, there is an opportunity to mitigate some of the problems with traditional and proportionate relief. In addition, the equitable relief provision should be interpreted in a manner consistent with a cohesive theory of the tax treatment of married individuals. There follows some suggestions along these lines.

127. As discussed above, imposing a further duty to investigate would be even more objectionable. For this reason, and also in order to comply with the legislative history, the Treasury Department and courts should interpret the "actual knowledge" test strictly.

128. Thus far, the Treasury Department has provided guidelines for relief in the specific situation noted in the legislative history-where an accurate return is filed but the other spouse fails to pay the reported tax liability-and has provided a list of factors to be taken into account in determining whether equitable relief should be available. See supra notes $45-47$ and accompanying text. 
One critical category of relief that remains to be fleshed out is the situation where traditional and proportionate relief are not available because the spouse seeking relief had knowledge (or in the case of traditional relief, reason to know would suffice) of erroneous items of the other spouse. The Treasury Department has indicated an unwillingness to provide relief in this situation. ${ }^{129}$ The Tax Court has disagreed in several cases, substituting its judgment that equitable relief was warranted even if the spouse had actual knowledge. ${ }^{130}$ This Article argues that a spouse's knowledge or reason to know of the other spouse's erroneous items is not a justifiable basis on which to impose liability. Accordingly, the Tax Court's approach is preferable, despite concerns about the Tax Court's disregard of administrative deference.

Another general category of relief that is likely to be controversial is the situation where traditional and proportionate relief are not available because an understatement (or underpayment) is attributable to erroneous items of the spouse seeking relief. Again, the Treasury Department has been reluctant to concede that equitable relief could ever be available, while the Tax Court reveals a more generous attitude toward taxpayers. ${ }^{131}$ This Article has argued that each individual is responsible for tax liabilities related to the individual's own activities. That an individual is married should not change this result. The equitable innocent spouse provision should be interpreted to preclude relief in this situation.

\section{Conclusion}

The principal tax rationale for joint and several liability-marital unity-is little more than a fiction adopted by lawmakers and scholars in order to rationalize a political compromise between community property and common law states. Furthermore, the other, secondary justifications for joint and several liability are unsatisfactory at best. Nonetheless, with the fiction of marital unity deeply embedded in our tax system, joint and several liability for married joint filers is likely to remain the law. While it can sometimes promote legitimate goals of fairness and efficiency, as an examination of joint and several liability in tort, agency and fraudulent conveyance law reveals, it can also produce unjust or irrational results. Where possible, therefore, the new innocent spouse laws should be interpreted and, in some cases, reformed to alleviate these injustices and irrationalities.

129. See supra notes $45-47$ and accompanying text.

130. See supra note 48 and accompanying text.

131. See supra notes $45-48$ and accompanying text. 